\title{
THE OCCURRENCE OF OIL DUCTS IN CERTAIN EUCALYPTS AND ANGOPHORAS.
}

By M. B. WeLCH, B.Se., A.I.C., Economic Botanist, Technological Museum.

(Plates xlii.-xlvi., and seven Text-figures.)

The presence, in the leaves, of oil glands or secretory eavities in varying number and mode of distribution, is a characteristic feature of the great majority of Eucalypts and Angophoras, though in several species, particularly in the latter genus, these glands are practically absent. In section these glands appear as ovate, elliptical, or circular eavities which, though varying in size and shape within small limits, are never elongated sufficiently to approach in any way what are known as "ducts," "canals" or "passages." Secretory passages differ from the typical secretory cavities only in their elongation; in origin they are schizogenous, lysigenous or schizolysigenous. They are found in a number of Natural Orders, particularly in the Coniferales, and may oceur in the pith, xylem, phloem or cortex. In some genera they are confined to the roots, in others they traverse the whole plant, or are limited to portions of the stem and leaves. Whatever their mode of distribution may be, they possess, without doubt, a marked taxonomic importance and value.

The oil-containing secretory ducts which are deseribed here as being present in certain species of the Eucalypts and Angophoras have apparently not yet been recorded. In fact, Solereder (1908) makes no mention of oil canals occurring in any of the Myrtaceae. Macalpine and Remfrey (1891) record, however, the presence of "Central canals," in the petioles of Eucalyptus calophylla, E. ficifolia and E. maculata "with its variety citriodora." In that paper the presence of oil is discounted and the contents are classed along with those of the cortical cavities of the petiole as being probably of a kinoid nature. There is no doubt, however, that oil, apparently similar in character to that in the leaf oil-glands, occurs in these canals, and further that tannin substances have not, so far, been found in them.

This investigation has shown that ducts oceur in the stems and leaves of the following Eucalypts and Angophoras:-E. Abergiana F. v. M. (Pl. xliii., fig. 6), E. calophyila R. Br. (Pl. xliii., fig. 4), E. corymbosa Sm. (Pl. xlii.; Fl. xliv., fig. 5; Pl. xlvi., figs. 1, 5-7), E. citriodora Hook. (Fl. xliii., fig. 3), E. dichromophloia F. v. M. (Pl. xlv., fig. 1), E. eximia Schau. (Pl. xliv., fig. 4), E. ferruginea Schau. (Pl. xliv., fig. 1), E. ficifolia F. v. M. (Pl. xlvi., fig. 2), E. Foelscheana F. v. M. (Pl. xlv., fig. 6), E. haematoxylon J. H. M. (Pl. xlv., figs. 2, 3), E. intermedia R. T. B. (Pl. xlvi., fig. 4), E. latifolia F. v. M. (Pl. xlv., fig. 5), 
E. maculata Hook. (Fl. xliii., fig. 1), E. peltata Benth. (Pl. xliv., fig. 3), E. pyrophora Benth. (Pl. xlv., fig. 4), E. terminalis F. v. M. (Pl. xliii., fig. 5), E. trachyphloia F. v. M. (Pl. xlvi., fig. 3), E. Watsoniana F. v. M. (Pl. xliv., fig. 2), Angophora lanceolata Cav. (Pl. xliii., fig. 2; Pl. xliv., fig. 6).

E. corymbosa, the common Bloodwood near Sydney, has been selected as being typical of the above species.

In the stems these canals or ducts are usually orientated towards the four corners of the pith, which is more or less rectangular in section, and oceur just within the intraxylary phloem, the vaseular bundles of the Eucalypts being bicollateral. They are typically four in number, though it is quite common to find fewer, and this number is often exceeded. An example of this is seen in E. haematoxylon (Pl. xlv., fig. 3) where nine canals occur. In Angophora lanceolata the young stems are usually somewhat triangular (Pl. xliv., fig. 6). This is reflected in the pith and in this species the number of ducts in the stem is commonly three, directed, as in E. corymbosa, to the corners. In a large number of Eucalypts now examined (over eighty species) I have found no indieation of ducts occurring-when they do oceur-in any part of the stem, other than the pith.

In the leaves, the eanals are found only in the mid-rib and never in conjunction with any of the lateral or intramarginal veins. In every species of
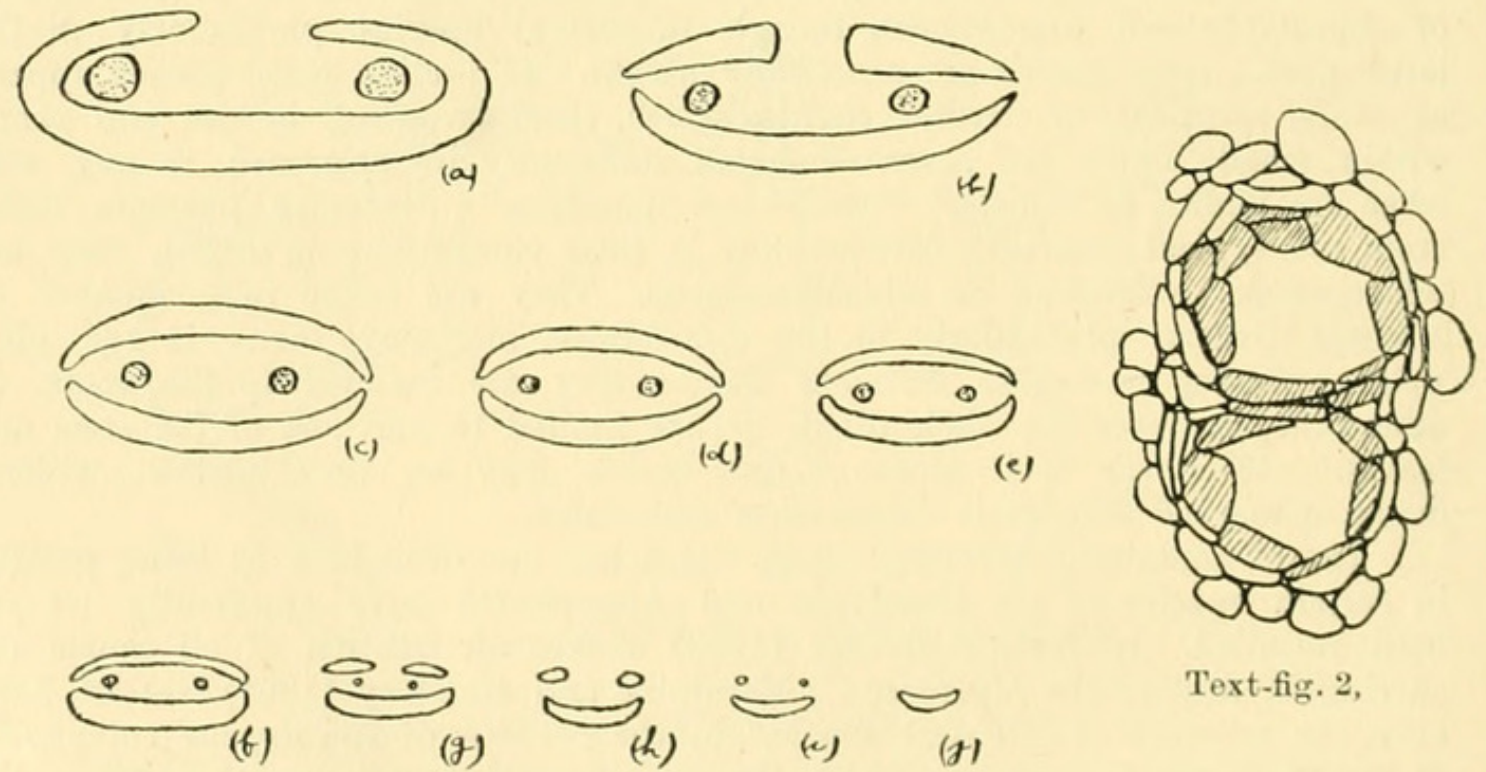

Text-fig. 2,

Text-fig. 1.-Transverse sections of a leaf nine inches in length, showing the diagrammatic arrangement of the ducts and xylem.

(a) T.S. petiole near stem; (b) T.S. petiole near lamina; (c) 1 inch from base of lamina; (d) 2 inches from base of lamina; (e) 3 inches from base of lamina; (f) 4 inches from base of lamina; ( $\mathrm{g}$ ) 5 inches from base of lamina; ( $\mathrm{h}$ ) 6 inches from base of lamina; (i) 7 inches from base of lamina; (j) 8 inches from base of lamina.

Text-fig. 2.-Two adjacent ducts in a young leaf of $E$. corymbosa which, however, do not show branching. The smaller duct only extends for a very short distance and is independent of the larger one. The shaded cells possess denser contents and are apparently, at this stage, epithelial in character.

Eucalyptus in which these ducts occur, the xylem of the principal leaf-vein forms two distinct, almost parallel, bands along the greater part of its length. This is shown somewhat diagrammatically in Text-fig. 1 (c.f.). 
In some cases one or both of these zones may be divided into smaller areas (see Pl. xliii., fig. 2), but as a rule the equal development of the xylem on both sides is a characteristic of these species. Text-fig. $1 \mathrm{~g}$ shows the upper zone of xylem divided into two, this section being taken at a point 5 inches from the junction of the petiole and lamina. In this section the ducts are $0.04 \mathrm{~mm}$. in diameter and disappear a very short distance further along the leaf. In the uppermost three inches of the leaf, represented in Text-fig. 1 by the 3 sections $h, i, j$, the ducts are absent, and the two smaller xylem areas also disappear in the last section. The only marked exception to this typical arrangement of the xylem is found in the mid-rib of Angophora lanceolata (Fl. xliv., fig. 6). The structure in this species is, however, typical of the vast majority of the Eucalypts examined, but in which ducts are wanting.

There is a gradual diminution in diameter as the canal passes along the petiole and through the lamina of the leaf. Where the petiole joins the stem the ducts are comparatively large, varying up to $0.35 \mathrm{~mm}$. in diameter in $E$. eximia. At the junction of the petiole and leaf blade they are somewhat smaller, and in the leaf are commonly $0.10 \mathrm{~mm}$. in diameter, showing a gradual reduction in size until at a point about $2 / 3$ of the distance from base to apex, they disappear.

Although two is the normal number of ducts in the leaf, it is quite common to find a third or fourth, seldom more. These arise independently alongside the others, in some cases in actual contact (Text-fig. 2), but evidence of branching is rarely found. These secondary ducts do not persist, as a rule, for any distance, and gradually taper off and disappear. In a few cases one of the
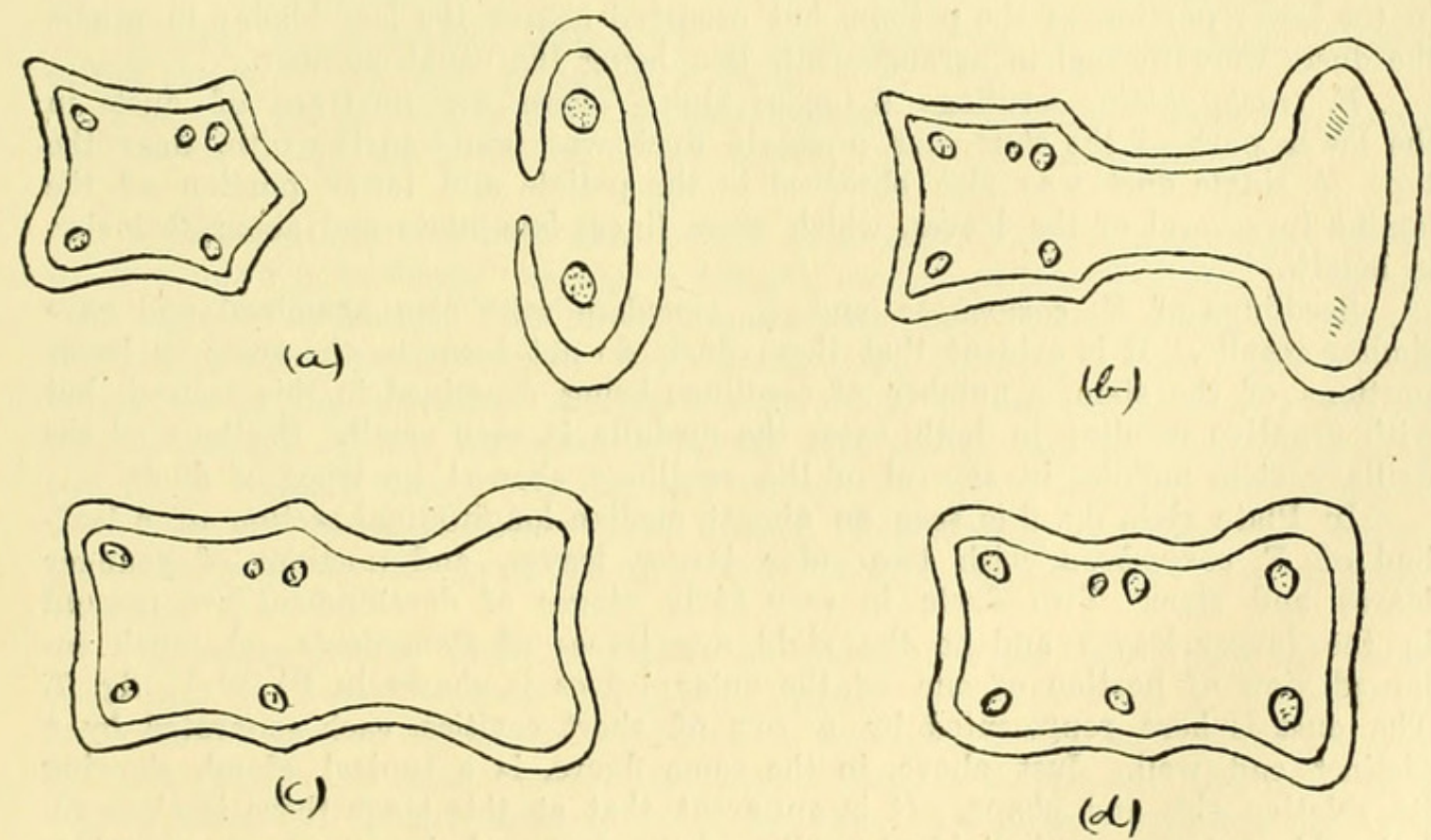

Text-fig. 3-Transverse sections of the junction of the stem and petiole of a mature leaf showing diagrammatic arrangement of the xylem and ducts.

main ducts may disappear, but only for a short distance, reappearing in the same relative position as before. The fact that the two leaf ducts are normally continuous for some distance is shown by the quantity of the exudation from them when cut transversely. This is particularly noticeable in the large 
leaves of Eucalyptus eximia, where medium-sized droplets appear on the eut surface. There is apparently a break in continuity of the ducts, however, where the petiole joins the stem. Text-fig. $3 a$ shows the arrangement of the xylem in the young stem (left) and petiole (right), and the distribution of the ducts in either case at the junction. In Text-fig. $3 b$ the vascular bundles in stem and petiole have joined up and, although there is no alteration in the number and arrangement of the ducts in the stem, in the petiole the positions of the ducts are marked only by a small quantity of thin-walled parenchymatous tissue with no cavity. In intermediate stages between $(a)$ and $(b)$ it is found that the cavity gradually becomes smaller, being encroached upon by thinwalled cells. Text-fig. $3 c$ shows that the "petiole" ducts have quite disappeared, although as before, the ducts in the stem show no alteration. 'In Text-fig. $3 d$, the two ducts reappear in a corresponding position to that which they occupied in the petiole, and are persistent down the stem. The non-continuity of the ducts is also noticed in the very early stages of development of the leaves, and will be dealt with later.

Seedlings of several of the species were obtained and an examination gave the following results:-

E. citriodora, seedling 18 inches high.-There was no trace of ducts below a distance of six inches from the hypocotyl. About 12 inches from the hypocotyl the ducts were well developed, there being four in the stem and two in the petiole and leaves. In the latter, however, they were only persistent for a comparatively short distance-about 1.5 inches in a leaf 5-6 inches in length.

E. eximia, seedling 24 inches high.-There was no clear evidence of ducts until about 15 inches from the hypocotyl. In some leaves ducts were not found in the lower portion of the petiole, but occurred nearer the leaf blade; in others the ducts were normal in arrangement, two being the usual number.

E. trachyphloia, seedlings 4 inches high.-There was no trace of ducts in the lower part of the stem, but a single duct was found in the pith, near the top. A single duct was also observed in the petiole and lower portion of the lanina in several of the leaves, which were linear-lanceolate and about 2 inches in length.

Seedlings of $E$. corymbosa and $E$. maculata were also examined and gave similar results. It is evident that these ducts do not oceur in the roots or lower portions of the stem, a number of seedlings being examined in this respect, but with negative results; in both eases the medulla is very small. Sections of the axillary stem nodules in several of the seedlings showed no trace of ducts.

In Plate xlvi., fig. 6 is seen an almost median longitudinal section of a leafbud of E. corymbosa, with two outer larger leaves, and portions of younger leaves and stem. Two ducts in very early stages of development are present in the larger leaves and on the right are traces of stem ducts. A much enlarged view of portion of one of the outer leaves is shown in Pl. xlvi., fig. 7 . The duct is here represented by a row of short eavities, each separated by a distinct end wall. Just above, in the same figure, is a typical gland, showing its relative size and shape. It is apparent that at this stage there is close relationship between an individual eavity of the duct and the oil gland. In older leaves and stems the end walls disappear completely, giving an elongated eavity which varies in length from less than $1 \mathrm{~mm}$. to $100 \mathrm{~mm}$. or more in the leaves, and evidently functions as a storage reservoir for the secreted oil. Two elongated cavities or ducts are shown in Plate xlvi., fig. 5, this being an approximately median section, parallel to the leaf surface of $E$. corymbosa. On either side of the primary vein a number of oil glands in the mesophyll are also seen, and it is evident that there is little in common in shape between them and the 
ducts. The duct is formed therefore by the linking up of a number of small eavities, each corresponding to a single oil gland, and formed by the division of a single meristematic cell in certain positions in the stems and leaves. Early stages in this development are shown in Text-fig. 4.

Subsequent division causes the formation of a group of cells, characterised by their denser contents, arranged in an almost spherical mass.
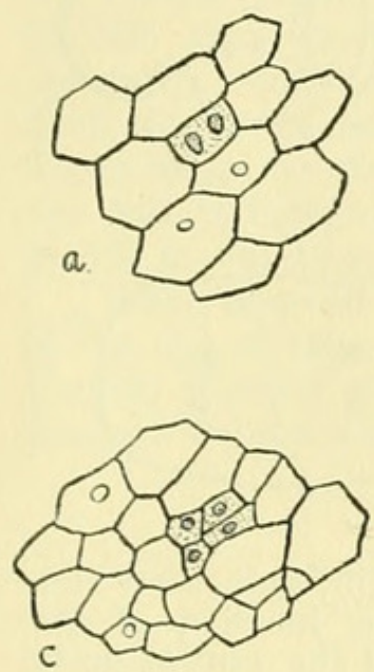
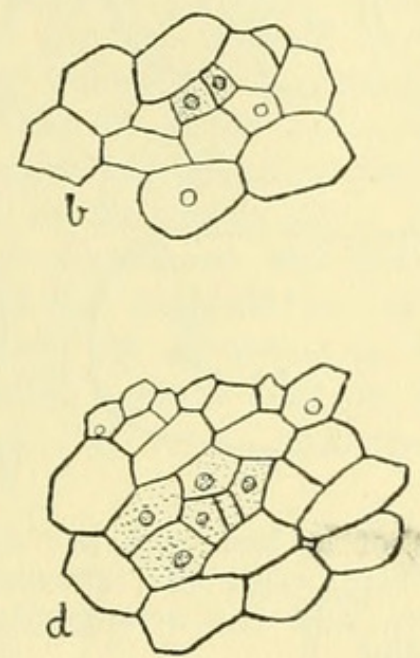

Text-fig. 4.
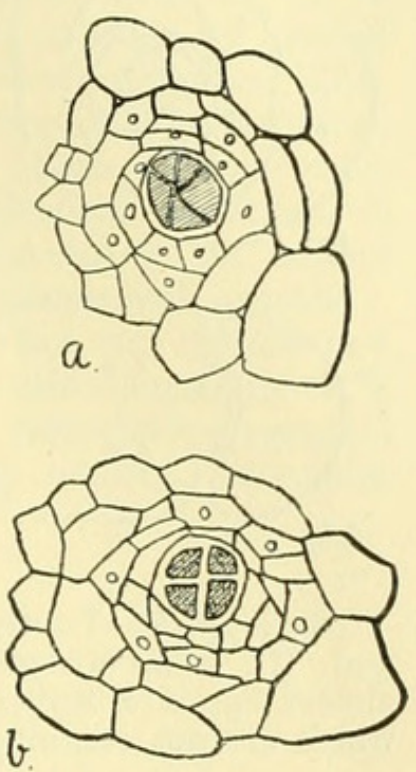

Text-fig. 5 .

Text-fig. 4--Transverse section of a stem apex of E. corymbosa showing initial stages in the development of a duct.

Text-fig. 5--Later stages in the development of the duct than are shown in Text-fig. 4, but the formation of the central cavity is just commencing.

Separation of these cells then occurs internally, early stages being shown in Text-fig. $5 a, b$, finally leaving a distinct central cavity (Text-fig. 1). There still remains a distinct wall of cells separating each eavity, until, as already mentioned, these barriers break down forming an individual duct. The central eavity has in the meantime enlarged considerably in section, evidently due to natural growth of the surrounding tissues and partly due to disintegration of the inner cellular tissue. Taking into account the mode of their formation, it is evident that these ducts are first formed lysigenously, and later on sehizogenously, a mode of formation to which Tschirch applies the term schizolysigenous.

In young leaves there is usually no trace of ducts until they are about $0.75 \mathrm{~mm}$. in width, whereas oil glands appear in leaves with a diameter of less than $0.2 \mathrm{~mm}$. They are never found in the apex of the stem or leaf, e.g. in Pl. xlvi., fig. 6 , the larger leaves are about $3 \mathrm{~mm}$. in length and the ducts only extend about $1 / 3$ of the distance from the base. As already pointed out, this is also a characteristic feature in mature leaves.

It is interesting to trace the course of these ducts in the leaf-bud; Textfig. 6 a shows a section through the numerous, almost opposite, leaves towards the apex of the bud of $E$. corymbosa, and, although ducts are well developed in the outer leaves, there is no trace of them yet in the inner ones; Text-fig. $6 \quad b$ is somewhat nearer the base of the bud, and shows a central stem with four very small duets in very early stages. On either side are the two axillary stems with no ducts, and outside these again are the petioles of the outer 
leaves, with two well-developed ducts in each; Text-fig. $6 c$, still nearer the base, shows the linking up on one side of one of the outer leaves with the stem, and it will be noticed that the ducts on this side have disappeared. In Textfig. $6 d$ the left hand petiole has almost fused with the stem but, although yet
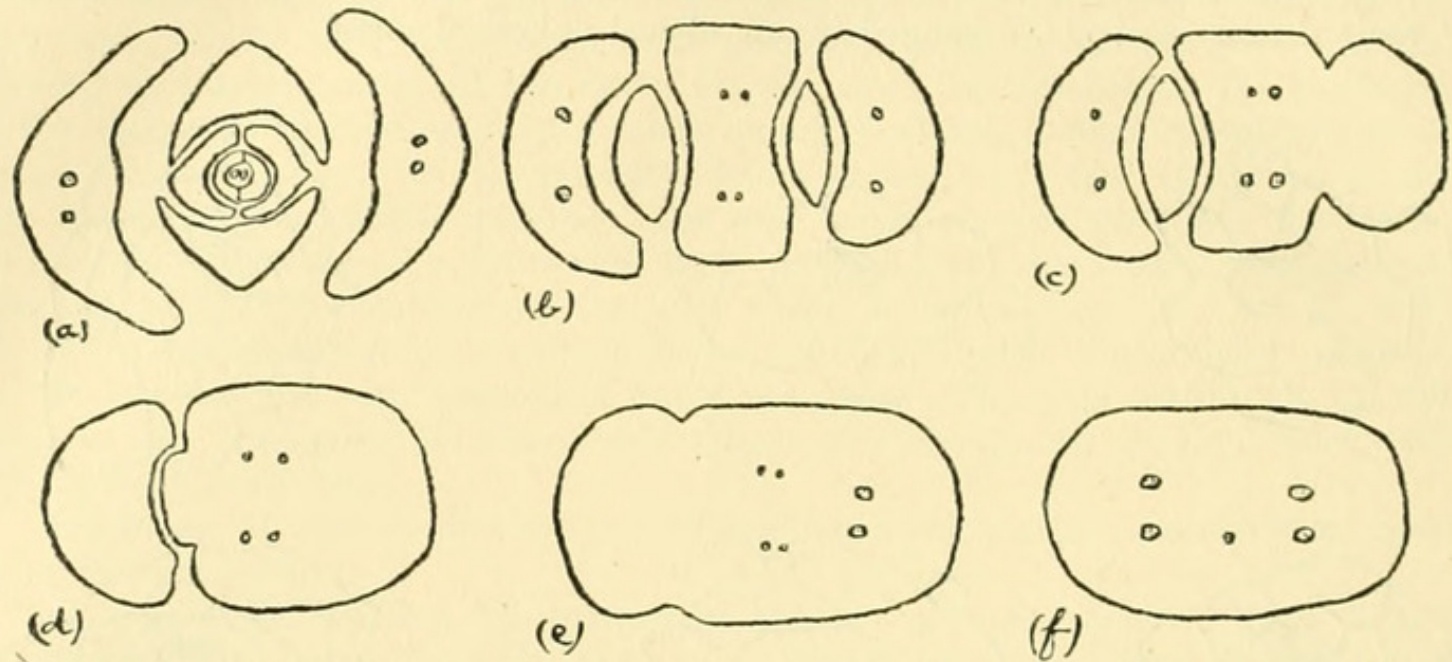

Text-fig. 6--Transverse sections of a leaf bud (a) and (b), and stem (e) and (f), with intermediate sections (c) and (d), showing the junction of the almost opposite leaves with the axis, and the arrangement of the central ducts which are not continuous at this point.

distinct, the ducts in this ease are also wanting. It will be seen that although almost opposite, the leaves show a tendeney to become alternate, a characteristic of the normal growth in this species. Text-fig. $6 e$ shows the complete linking up of both outer leaves with the stem, and the reappearance on the right of two ducts in a position in the stem corresponding to that occupied whilst in the petiole. In Text-fig. $6 f$ the ducts have also reappeared on the left hand side, and it is a striking feature that three of the original stem ducts have disappeared, and the fourth is much reduced in size. This reduction in number of the ducts accounts for the usual appearance of four in the stem, although as already pointed out this number is often exceeded.

The presence of a definite epithelium within the cavity is not always characteristic of these ducts. In many cases an epithelial lining doubtless exists (Text-fig. 1), and in a number of sections the eavity is almost blocked by rows of more or less concentrically arranged thin-walled cells. In other eases, particularly in older stems and leaves, there is no trace of any definite epithelial layer, which probably undergoes disintegration.

\section{Contents of Secretory Ducts.}

In all those species of which fresh material could be obtained the contents of the secretory ducts were examined in situ. They were found to be yellowish in eolour as a rule, though sometimes almost eolourless, and usually granular in appearance under the microseope, owing to a number of small globules being present. Treatment with increasing strength of alcohol had little or no effect until $90 \%$ was reached. Here contraction oceurred, the contents usually going into final solution in $95-100 \%$ alcohol. This solubility of the contents of the duct is in accord with the results obtained for the oil in the mesophyll glands of E. corymbosa. 
Some of the exudation from a cut stem was transferred to a slide and, as before, solution occurred in $95 \%-100 \%$, usually in the former. In some cases a very small, clear, film-like residue was left, which was insoluble in ehloroform or ether.

Sections of fresh leaves stained in a solution of alkannin in $50 \%$ alcohol showed the characteristic bright red colouration in the ducts, indicating the presence of oil. Cyanin in $50 \%$ alcohol also gave a positive reaction for oil in the central ducts. Glacial acetic acid, and also aqueous solution of chloral hydrate gave complete solution. The Unverdorben Franchimont reaction (Zimmerman), using copper acetate, showed the normal colouration for terpenes. Tests for tannin gave no indications in the central ducts or in the adjacent cells. There seems no doubt that oil occurs in these central ducts, and is similar, at any rate in behaviour under microchemical tests, to that oceurring in the normal glands in the mesophyll of the leaves or in the cortex of stems and petioles.

Some material of $E$. corymbosa was soaked in water for six months and at the end of this period the contents of the ducts were still soluble in $95 \%$ alcohol, showing apparently no alteration in this respect. Nevertheless material fixed in "chromacetic acid," picric acid in $50 \%$ or $95 \%$ alcohol, "formalin
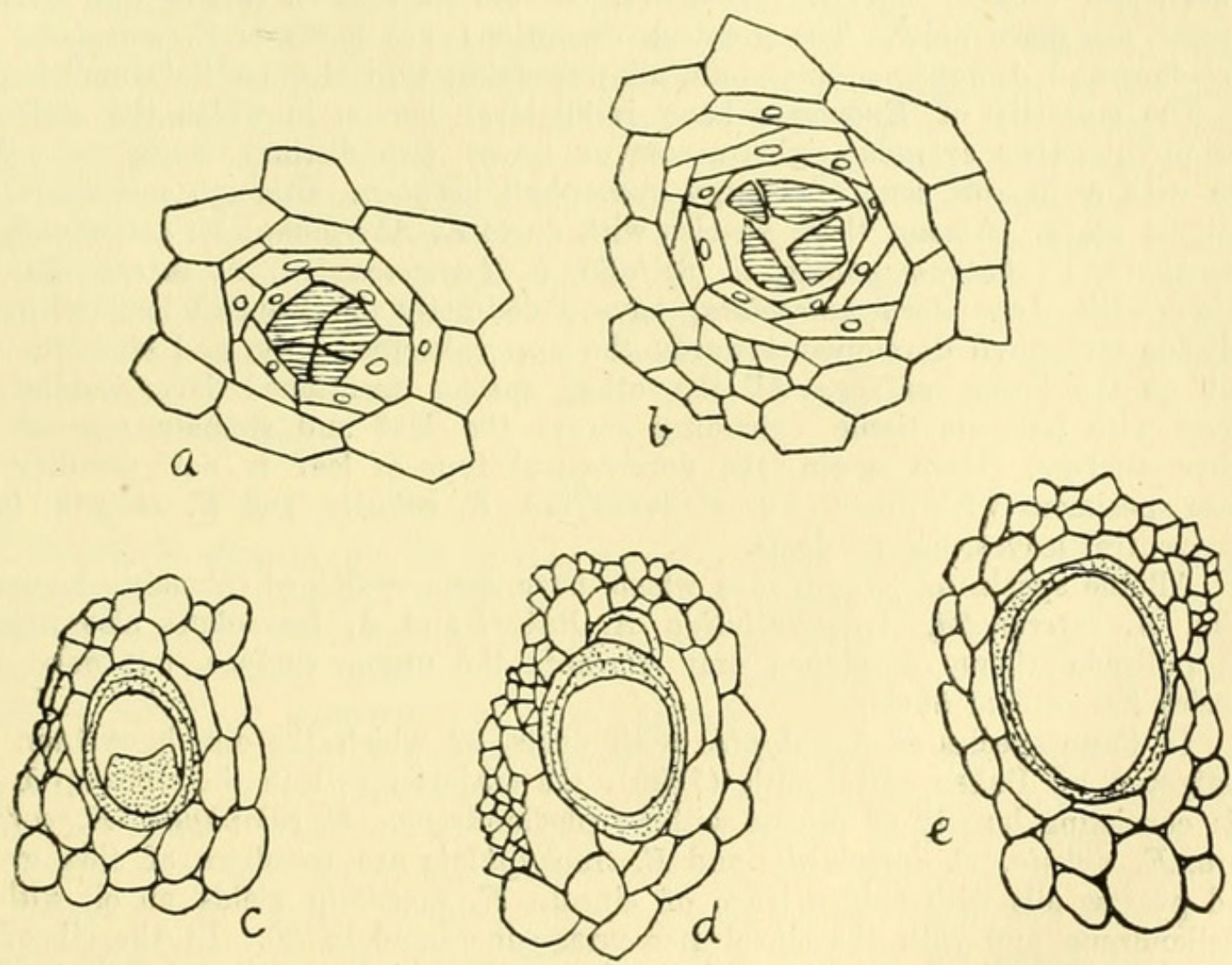

Text-fig. 7-Ducts in section showing the insoluble residue, (a) and (b) in early stage of development, (c), (d) and (e) later stages in which a lining is found in the cavity.

alcohol" or even ordinary $95 \%$ alcohol, shows an insoluble residue, often in the form of a complete ring surrounding the duct when seen in section (Text-fig. 7 $c-e)$, or in the cells. It is also noticeable in sections eut from dried leaves. This insoluble residue is sometimes found scattered irregularly in the duct, apparently retaining the outline of the cells in which it was at one time enclosed (Text-fig. $7 a, b)$. It is apparently an oxidation product derived from the 
eontents of the duct or surrounding cells, and is also found in the oil glands in the leaf. When material is sectioned fresh and transferred direct to $95 \%$ alcohol, the ducts and oil glands are found to be free from this residue.

There are certain resemblances or affinities between the species of Eucalyptus possessing central ducts. Perhaps the most obvious of these are the "Bloodwood" fruits, more or less urceolate in shape, though the presence of urceolate fruits does not necessarily signify ducts, e.g., E. Planchoniana, a "Stringybark" from northern N.S.W., has a very similar fruit to that of E. calophylla, the Red Gum of Wiestern Australia, but there is no evidence of ducts in the former species. Another exception is the Tasmanian E. urnigera, * with particularly urceolate fruits. Other exceptions are also found. The leaf venation is characteristic; in all species with ducts, the lateral veins are very transverse, in some cases almost at right angles to the midrib, close and numerous, while the intramarginal vein is very near to the edge. Angophora lanceolata is also in this class. The converse however does not hold, e.g. E. saligna, E. robusta, and $E$. resinifera, possess lateral veins which are quite transverse, but no ducts oceur. The barks of these species show great variation. The great majority fall into the "Bloodwood" group, the bark being, in some cases, short fibred, friable, and broken, e.g. E. corymbosa. Others such as E. eximia and E. terminalis are more flaky. The greatest exceptions are however $E$. maculata; $E$. citriodora and Angophora lanceolata, all possessing typical smooth "Gum" barks.

The majority of Eucalypts have isobilateral leaves, in which the palisade mesophyll either extends right across or forms two distinct zones on either side with a narrow zone of spongy mesophyll between, although numerous exceptions oceur. Among these species with ducts E. Abergiana, E. calophylla, E. corymbosa, E. dichromophloia, E. ficifolia, E. haematoxylon, E. intermedia, together with Angophora lanceolata, have a distinctly dorsiventral leaf with the palisade mesophyll developed towards the upper surface only, and stomata present on the lower surface. All the other species mentioned have isobilateral leaves with palisade tissue extending across the leaf and stomata present on either surface. Here again the dorsiventral type of leaf is not peculiar to those specimens with ducts, e.g. E. resinifera, E. robusta, and E. saligna have dorsiventral leaves, but no ducts.

All the species of Angophora which have been examined, namely, A. cordifolia, A. intermedia, A. subvelutina, A. Bakeri and A. lanceolata, also possess the palisade tissue developed only towards the upper surface, but only one species has central ducts.

In those species of Eucalyptus with ducts, of which the oils have been investigated by Baker and Smith (1920), the majority fall in their Group 1, i.e. oils consisting largely of pinene without phellandrene. E. calophylla, E. corymbosa, E. eximia, E. intermedia and E. trachyphloia are members of this group and possess oils with only a trace of cineol. E. maculata yields an oil without phellandrene and with the eineol percentage increased to 20 . In the oil of $E$. citriodora there is no cineol or phellandrene, the chief constituent being citronellal. These authors state that the oil of $E$. terminalis was not investigated as the number of glands in the leaf was so small. Smith (1914), in a paper on the essential oils of the Angophoras, points out the great similarity between the oil of A. lanceolata and those obtained from the "Bloodwood" group of Eucalypts.

Cuthbert Hall (1914), on the evidence of cotyledons, places in the Bloodwood or Corymbosa group the following species: E. calophylla, E. perfoliata, E. eximia, E. corymbosa, E. trachyphloia, E. citriodora, E. maculata, and E. intermedia. With one exception, $E$. perfoliata, in which ducts have not yet

- E. tesselaris is also an exception. 
been observed, these species eontain central ducts. Among the species which he predicted would fall in the same class are E. Abergiana, E. dichromophloia, E. ferruginea, E. Foelscheana, E. peltata, E. pyrophora, E. terminalis and E. Watsoniana.

Bentham (1866), on anthereal evidence, places in the Corymbosae the majority of the species then described, and now found to possess ducts. The only exception is $E$. trachyphloia, which, though placed in the Micrantherae, was apparently classified on imperfect evidence.

As already mentioned, those species of Eucalyptus with ducts possess a mid-rib which, for the greater part of the length of the leaf, has the xylem in two more or less equal zones. Species such as $E$. setosa, E. miniata, E. phoenicea, E. perfoliata, E. clavigera and E. tesselaris, however, have a similar vascular bundle in the mid-rib, but so far, in the material examined, ducts have not been found. Except in the case of $E$. tesselaris, however, fresh material was not available.

Geographically these species are distributed through Western Australia, and Northern Territory, extending into Northern South Australia, Queensland, and New South Wales, while one species extends into Victoria. With this exception, species with ducts do not oceur in Victoria or Tasmania.

From an evolutionary standpoint, the presence of these ducts in certain species of the Angophoras and Eucalypts adds another argument to the theory of their common ancestry put forward by Baker and Smith. In no other genera of the Tribe Leptospermeae, have similar central oil ducts been observed - at any rate in those species worked on-though, as shown, the oceurrence of these canals is purely a specific character. The closely allied genus Tristania, however, has a well developed lactiferous system in at least one species. It therefore seems probable that the species of Eucalyptus with ducts are the oldest members of the genus, and that this character has been entirely lost in the later types, which evolved for the most part smaller fruits, isobilateral leaves and a more oblique leaf venation.

\section{SumMary.}

Oil ducts, formed by the linking up of a chain of short secretory eavities, corresponding in size and formation to the oil glands in the leaf, oceur in the stems and leaves, both normal and abnormal, of certain Eucalypts and Angophoras. So far, they have not been found in any other genera of the Leptospermeae, and their oceurrence is purely specific.

There is no direct connection between these central ducts and the leaf, petiole or stem oil glands, though both structures apparently possess an oil of a similar nature. They are not kinoid in eharacter. These ducts are not continuous in stem and leaves, but show a break at the petiole. They are variable in diameter and length, ranging from $0.3 \mathrm{~mm}$. to less than $0.03 \mathrm{~mm}$. in the former and from over $100 \mathrm{~mm}$. to less than $1 \mathrm{~mm}$. in the latter dimension. They apparently function as storage reservoirs.

No evidence has been found so far to show that these ducts oceur in the roots and they have not been observed in the lower portions of the stems of seedlings.

The presence of these central canals in a very limited number of Eucalypts, all of the Corymbosae class, indicates their primitive character, and their oceurrence also in one species of Angophora, shows apparently a close phylogenetic affinity between the two genera, Angophora and Eucalyptus.

In conclusion I should like to express my indebtedness to Mr. J. H. Maiden, 
I.S.O., F.R.S., for his courtesy in allowing me to obtain material of many of the rarer Eucalypts from the Botanic Gardens. I am also indebted to Mr. R. T. Baker, Professor Lawson and Dr. MeLuckie for kindly advice and criticism throughout the work.

\section{List of References.}

BaKłer, R. T., and Sмith, H. G., 1920.-A research on the Eucalypts, especially in regard to their Essential Oils, 1st Ed. 1902, 2nd Ed. 1920, Dept. of Education, N.S.W., Technical Education Series Nos. 13 and 24.

Bentham, 1866.-Flora Australiensis. Vol. 3.

Haberlandt.-Physiological Plant Anatomy.

HaLl, C., 1914.-The Evolution of the Eucalypts in relation to the Cotyledons and Seedlings. Proc. Linn. Soc. N.S. Wales, xxxix., 1914, p. 473.

MaCalpine and Remfrey, 1891.- The transverse sections of Petioles of Euealypts as aids in the determination of species. Trans. Roy. Soc. Vic., ii., pt. 1, p. 1. Smith, H. G., 1914.-On the Essential Oils of the Angophoras. Proc. Roy. Soc. N.S.W., Vol. 47, 1913, p. 106.

SOLEREder, 1908.- Systematic Anatomy of the Dicotyledons. English translation, Oxford.

Zimmerman.-Botanical Microtechnique.

EXPLANATION OF PLATES XLII.-XLVI.

Plate xlii.

E. corymbosa Sm. Transverse section of a portion of a leaf showing typical arrangement of the two central oil ducts in the medulla between the two parallel bieollateral vaseular bundles. The almost equal distribution of the xylem in two bands along the greater portion of the leaf is typical of Eucalypts of the Corymbosae group. The palisade tissues are developed towards the upper surface only in this species.

\section{Plate xliii.}

Fig. 1. x 55; Fig. 2. x 80; Fig. 3. x 110; Fig. 4. x 60; Fig. 5. x 70; Fig, 6. $\mathrm{x} 50$.

Fig. 1.

E. maculata Hook. Transverse leaf section with two duets, in which a small dark residue remains. This section was made from dried material. The palisade extends right across the lamina, and stomata oceur on either surface.

Fig. 2.

Angophora lanaeolata Cav. Transverse leaf section. This is the only genus of the Myrtaceae, outside the Eucalypts, in which central oil ducts have so far been found. The xylem of the mid-rib in this species more nearly approaches that found in the majority of Eucalypts, though in some material there was a tendency towards the E. corymbosa type. The contents of the ducts (normally two) are light yellow in colour and soluble in 95-100 per cent. alcohol. As in the other Angophoras the palisade tissue is found towards the upper surface only, though this is the only species of the genus in which ducts have so far been observed.

Fig. 3.

E. citriodora Hook. Transverse leaf section. Two ducts are usually found in this speeies. The palisade tissues extend right across the leaf, and stomata oceur on both surfaces.

Fig. 4 .

E. calophylla $\mathrm{R}$. Br. Transverse leaf section in which two ducts are present, 
though almost completely blocked by a dark insoluble residue. In this case the palisade tissues only oecur towards the upper surface. This section was cut from dried material

Fig. 5.

E. terminalis F. v. M. Transverse leaf section with one duct. In some material of this species examined there was no evidence of ducts, which are apparently not well developed in the species. The palisade tissue extends right across the leaf, and stomata oceur on either surface.

Fig. 6.

E. Abergiana F. v. M. Transverse leaf section with two ducts. The palisade tissues are developed towards the upper surface only, and stomata occur on the lower side.

Plate xliv.

Figs. 1 and 2. $x$ 45; Fig. 3. $x$ 55; Fig. 4. $x$ 50; Fig. 5. $x 13$; Fig. $6 . x 17$. Fig. 1.

E. ferruginea Schau. Transverse leaf section with two ducts. The palisade tissue consists of long narrow cells and extends right across the leaf; stomata are found on either surface.

Fig. 2.

E. Watsoniana. Transverse leaf section with two small ducts. The palisade tissue extends right across the leaf, and stomata are developed on either surface. The upper xylem band in this section shows a decided break at a point nearer the petiole than is usual.

Fig. 3.

E. peltata Benth. Transverse leaf section with two ducts. The contents are bright yellow in colour and soluble in 90 per cent. alcohol. The palisade extends right across the leaf, and stomata are equally developed on either side.

Fig. 4.

E. eximia Schau. Transverse leaf section with three distinct central ducts, though two are normal. The eontents are usually elear, light yellow, soluble in 90-95 per cent. alcohol. In this species a red pigment is often found in the hypodermal cells of the mid-rib. The palisade tissue extends practically right across the leaf, and stomata are on either surface.

Fig. 5.

E. corymbosa $\mathrm{Sm}$. Transverse section of stem showing normal arrangement of four ducts in the corners of the pith.

Fig. 6.

A. lanceolata Cav. Transverse section of young stem showing three oil ducts oriented towards the angles of the pith.

Plate xlv.

Fig. 1. x 50; Figs. 2, 3 and 6. x 30; Fig. 4. x 70 ; Fig. 5. $\mathrm{x} 40$.

Fig. 1.

E. dichromophloia F. v. M. Transverse leaf section with two small central ducts. In the material examined of this species only one leaf duct was often found with very little contents which were soluble in 90 per cent. alcohol. The palisade tissue is directed towards the upper surface only. In the stems two ducts were usually found, almost filled with thin-walled cellular tissue.

Fig. 2.

E. haematoxylon J. H. M. Transverse leaf section with three central ducts, though two were normal in the material examined. Contents very pale yellow in colour and soluble in 90 per cent. alcohol. The palisade tissue is developed towards the upper surface, and stomata oceur only on the lower epidermis. 
Fig. 3.

E. haematoxylon J. H. M. Transverse section of stem showing nine ducts, five of which are abnormal. There are also four oil glands present in the cortex.

Fig. 4.

E. pyrophora Benth. Transverse leaf section with two duets almost completely closed by a dark residue. There are also several phloem earities as this material was dry when examined. The palisade tissue extends right across the leaf.

Fig. 5.

E. latifolia F. v. M. Transverse leaf section with three ducts, one of which retains a dark residue. Small phloem cavities are seen also in this section, which was made from dried material. The palisade extends right across the leaf, and stomata are developed on either side.

Fig. 6.

E. Foelscheana F. v. M. Transverse leaf section with only one duct, the number usually found in the dried material examined. The numerous large eavities in this section are due to the disintegration of the intraxylary phloem, apparently caused by the pressing during preparation as a herbarium specimen and subsequent softening of the leaf for sectioning. The palisade tissues extend right across the lamina.

Plate xlvi.

Fig. 1. x 30; Figs. 2, 4 and 5. x 50; Fig. 3. x 65; Fig. 6. x 20; Fig. 7. x 155 . Fig. 1.

E. corymbosa Sm. Transverse section of petiole showing two ducts. These are usually larger in diameter than those in the leaf.

Fig. 2.

E. ficifolia F. v. M. Transverse leaf section with two ducts. The contents are usually colourless or very pale yellow, minutely granular, and soluble in 90 per cent. alcohol. The palisade is developed towards the upper surface only, and stomata are found on the lower epidermis.

Fig. 3.

E. trachyphloia F. v. M. Transverse leaf section with two ducts, the contents being usually light yellow and soluble in 95 per cent. alcohol. The palisade shows greater development towards the upper surface, and stomata are found on the lower side only.

Fig. 4.

E. intermedia R. T. B. Transverse leaf section with two comparatively large ducts, containing a small amount of residue; this section being obtained from dried material. The palisade mesophyll consists of one or two rows of cells towards the upper epidermis.

Fig. 5.

E. corymbosa Sm. Median section parallel to the leaf surface with two oil ducts in the mid-rib. On either side are a number of oil glands distributed in the mesophyll of the leaf.

Fig. 6 .

$E$. corymbosa $\mathrm{Sm}$. Median longitudinal section through a leaf bud showing two leaf ducts, and on the right are evidences of two stem ducts. There is no direct connection between these two systems of ducts.

Fig. 7 .

E. corymbosa Sm. Portion of one of the leaves in the preceding figure under a greater magnification, showing the "duct" composed of a row of small elongated cavities, corresponding in size and shape to the oil gland seen above. By the breaking down of the transverse walls the passage becomes continuous. 


\section{$2 \mathrm{BHL}$ Biodiversity Heritage Library}

Welch, M. B. 1921. "The occurrence of oil ducts in certain eucalypts and angophoras." Proceedings of the Linnean Society of New South Wales 46, 475-486. https://doi.org/10.5962/bhl.part.14035.

View This Item Online: https://www.biodiversitylibrary.org/item/23930

DOI: https://doi.org/10.5962/bhl.part.14035

Permalink: https://www.biodiversitylibrary.org/partpdf/14035

\section{Holding Institution}

MBLWHOI Library

\section{Sponsored by}

MBLWHOI Library

\section{Copyright \& Reuse}

Copyright Status: NOT_IN_COPYRIGHT

This document was created from content at the Biodiversity Heritage Library, the world's largest open access digital library for biodiversity literature and archives. Visit BHL at https://www.biodiversitylibrary.org. 